\title{
Technology of landscaping in arid zones by using biohumus from sheep wool
}

\author{
Alibek Ydyrys ${ }^{1 *}$, Birlikbay Yeszhanov ${ }^{2}$, Nurlan Baymurzaev ${ }^{2}$, Sayat Sharakhmetov ${ }^{2}$, \\ Askar Mautenbaev ${ }^{2}$, Bekzat Tynybekov ${ }^{2}$ and Tilek Baidaulet ${ }^{2,3}$ \\ ${ }^{1}$ Al-Farabi Kazakh National University, Biomedical Research Centre, 71 al-Farabi Ave. \\ 050040 Almaty, Kazakhstan \\ ${ }^{2}$ Al-Farabi Kazakh National University, 71 al-Farabi Ave. 050040 Almaty, Kazakhstan \\ ${ }^{3}$ Asfendiyarov Kazakh National Medical University, 94 Tole bi 2050000 Almaty, Kazakstan
}

\begin{abstract}
The problem of greening the arid zones in Kazakhstan and in the world, as well as addressing water shortages in agriculture in these areas, requires new ideas or innovative technologies. We used sheep's wool to create biohumus in combination with desert soils. In Kazakhstan sheep's wool is considered useless, although it is rich in bioresources. Our research shows that biohumus obtained from sheep's wool is highly fertile in laboratory experiments, and for it the need to use water is 3 times less than for other soils. Under laboratory conditions, we have proven that biohumus can be used to grow plants in different ecological zones. Its use in the wild/field can solve several problems of greening dry areas and growing food crops in low humidity conditions. In addition, it can increase the value of sheep's wool as a bio resource. It is thus an economically promising technology that meets the environmental standards of a green economy.
\end{abstract}

\section{Introduction}

The development of safe food production and increasing agricultural productivity for human are considered in parallel with the current biodiversity conservation problem $[1,2]$. This is particularly important for countries with a harsh climate located in arid zones such as Kazakhstan. Currently, the problem of the impact of cold as a limiting adverse environmental factor is one of the important problems in Kazakhstan for the development of agricultural areas, and there are also acute problems of desertification, declining fertility and soil degradation, as well as lack of irrigation water. These problems are caused by irrational water use, outdated irrigation systems and are aggravated by growing rates of deforestation, excessive grazing and high vulnerability of the region to climate change. There are several works in this direction, which are related to the impact of low positive temperatures, severe environmental and climatic conditions on plant growth processes [3]. New ideas or innovative technologies are needed to address water shortages in agriculture, greening and agricultural development in the arid zones of Kazakhstan and the world. Some researchers have attempted to quantify the impact of the "Grain for Green" program on water ecosystem

\footnotetext{
* Corresponding author: ydyrys.alibek@gmail.com
} 
services for arid and semi-arid China [4] and recommended an alternative system called "Ecological Agriculture" to address the problems of modern, highly productive agriculture [5]. Nano-hydrophobic sands allow achieving a rich crop yield per unit area and reducing the amount of irrigation water [6].

Humus is a "medicine" for soil, "bread" for plants. Biohumus is the basis of ecologically safe agriculture and the way to sustainable agriculture in the 21 st century. There are different scientific methods of its creation, using different raw materials. We have used sheep's wool, which is an easily accessible and cheap resource in Kazakhstan, to create a new biogumus. Sheep wool is considered as useless but rich bio-resources in Kazakhstan. The results of laboratory testing of the biogumus obtained in combination of desert soils with purified and synthesized sheep's wool are presented below.

\section{Materials and Methods}

For the production of biohumus we used waste in the form of contaminated sheep wool as raw material. First, the sheep's wool was cleaned in the LLUFHB006-100 washing and drying machine. Then we mixed sheep's wool powder and dry soil in a ratio of 1:10.

For methodical study, we collected four types of soil on which we cultivated seedlings of legumes. The first control group of soils was taken from the arid zones and was well moistened, the second group was represented by black soil, the third group of soils consisted of our biohumus, and the fourth group had arid soils.

The research is conducted by direct biotesting. By the growth of root system and seedlings in relation to the control we can judge about the possibility of using biohumus mixed with soil for growing grains.

First of all, we took bean grains for germination as a test object. $100 \mathrm{~g}$ of biohumus was mixed with $50 \mathrm{ml}$ of distilled water and placed in a Petri dish, covered with filter paper, then 20 grains of bio-test were placed. Control was carried out by germination of bio-test grains in distilled water. By the growth of root system and seedlings in relation to the control we can determine the degree of impact of pure biohumus on the test object.

Then we grew the seedlings for four weeks. Each week we measured the height of the plants, marked the phases of plant development (flowering and fruiting) taking into account the total weight of the crop per $1 \mathrm{~m} 2$ of each experimental group, the area of each experimental group and the nitrogen, phosphorus and potassium content.

Testing of protein, phosphorus and potassium content was conducted by biochemical analysis in laboratories.

\section{Results and discussion}

The experiments were conducted by laboratory of Faculty of biology and biotechnology of Al-Farabi Kazakh National University. The plot area is $10 \mathrm{~m}^{2}$.

The table 1 shows control group growing well in all four weeks. Since dry soils evaporate water quickly, the first control group we had to swim three times as often as the other groups. The second group grew well in the 1 st week, but from the 2 nd week the condition of the plants becomes average. The third group's performance is excellent all week long. As it turned out, our biohumus has the ability to preserve water for a long time. Plants in group 4 slowly die within four weeks due to lack of water. Research conducted by direct biotesting. 
Table 1. Growth dynamics of seedlings of beans on different soils

\begin{tabular}{|c|c|c|c|c|c|c|c|c|}
\hline & \multicolumn{2}{|c|}{$1^{\text {st }}$ week } & \multicolumn{2}{|c|}{$2^{\text {nd }}$ week } & \multicolumn{2}{|l|}{$3^{\text {rd }}$ week } & \multicolumn{2}{|l|}{$4^{\text {th }}$ week } \\
\hline & $\begin{array}{l}\text { seedling } \\
\text { length } \\
\mathrm{mm}\end{array}$ & \begin{tabular}{|l|} 
root \\
system \\
length, \\
$\mathrm{mm}$
\end{tabular} & $\begin{array}{l}\text { seedling } \\
\text { length } \\
\mathrm{mm}\end{array}$ & \begin{tabular}{|l|} 
root \\
system \\
length, \\
$\mathrm{mm}$
\end{tabular} & \begin{tabular}{|l|} 
seedling \\
length \\
$\mathrm{mm}$
\end{tabular} & \begin{tabular}{|l|} 
root \\
system \\
length, \\
mm \\
\end{tabular} & $\begin{array}{l}\text { seedling } \\
\text { length, } \\
\mathrm{mm}\end{array}$ & \begin{tabular}{|l|} 
root \\
system \\
length, \\
mm
\end{tabular} \\
\hline Control & $3.2 \pm 0.3$ & $4.1 \pm 0.2$ & $\begin{array}{c}10.1 \pm \\
0.52\end{array}$ & $\begin{array}{c}12.5 \pm \\
0.81\end{array}$ & $\begin{array}{c}21.11 \pm \\
0.63\end{array}$ & $\begin{array}{c}26.1 \pm \\
0.22\end{array}$ & $\begin{array}{c}39.13 \pm \\
0.24\end{array}$ & $\begin{array}{c}40.5 \pm \\
0.71\end{array}$ \\
\hline Black soil & $3.5 \pm 0.6$ & $\begin{array}{l}4.8 \pm \\
0.51\end{array}$ & $\begin{array}{l}8.6 \pm \\
0.31\end{array}$ & $\begin{array}{c}10.7 \pm \\
0.26\end{array}$ & $\begin{array}{c}17.4 \pm \\
0.51\end{array}$ & $\begin{array}{c}19.3 \pm \\
0.46\end{array}$ & $\begin{array}{l}31.81 \\
\pm 0.46\end{array}$ & $38 \pm 0.37$ \\
\hline Biohumus & $\begin{array}{c}3.11 \pm \\
0.4\end{array}$ & $4.4 \pm 0.7$ & $\begin{array}{l}9.7 \pm \\
0.33\end{array}$ & $\begin{array}{c}11.3 \pm \\
0.31\end{array}$ & $\begin{array}{c}24.61 \pm \\
0.28\end{array}$ & $\begin{array}{c}32.14 \pm \\
0.35\end{array}$ & $\begin{array}{c}56.5 \pm \\
0.76\end{array}$ & $\begin{array}{c}67.3 \pm \\
0.27\end{array}$ \\
\hline Desert soil & $2.4 \pm 0.6$ & $\begin{array}{l}3.1 \pm \\
0.53\end{array}$ & $\begin{array}{l}5.7 \pm \\
0.41\end{array}$ & $\begin{array}{l}8.4 \pm \\
0.33\end{array}$ & $7.6 \pm 0.4$ & $\begin{array}{c}10.7 \pm \\
0.23\end{array}$ & 0 & 0 \\
\hline
\end{tabular}

After 4 weeks of cultivation, we analyzed the chemical composition of the bean sprouts in a biochemical laboratory (percentage by dry matter). We measured the amount of potassium, phosphorus and protein fraction per $100 \mathrm{mg}$. As can be seen from Table 2The chemical composition of plants grown in the new biohumus is slightly inferior to that of the control and chernozem groups.. At the same time, as can be seen from Table 1, the length of seedlings grown in biohumus $(56.5 \pm 0.76)$ and the length of their root system $(67.3 \pm$ 0.27 ) is significantly higher than in other groups, probably due to water retention properties of biohumus. This indicates that when using sheep's wool biohumus, the minerals required for plant growth remain available.

Table 2. Macronutrients and protein content in the bean sprouts

\begin{tabular}{|l|c|c|c|}
\hline Groups & \multicolumn{3}{|c|}{ Macronutrients (100 mg,\%) } \\
\hline Control & Potassium & Phosphorus & Protein \\
\hline Black soil & 1.8 & 6.1 & 0.57 \\
\hline Bio-Humus & 2 & 6.8 & 0.6 \\
\hline Desert soil & 1.7 & 5.6 & 0.54 \\
\hline
\end{tabular}

The first signs of nitrogen, potassium and phosphorus deficiency are weak and stunted shoots, leaves with yellowness or pale green. Potassium as an element is needed to increase productivity, resistance to drought, low temperatures, fungal diseases. The first signs of potassium starvation are the barely noticeable withering of leaves and a decrease in their elasticity, the appearance of white borders along the leaf edge, which subsequently turns brown. Phosphorus-containing fertilizers strengthen the root system of plants, increase their resistance to adverse weather factors, provide full ripening of fruits. They are applied in autumn when digging the soil or in nearbore circles with organic matter. Nitrogen is one of the most important elements for plant growth. Fertilisers are applied directly to the soil during spring digging (urea) and in dissolved form (ammonium nitrate). Based on the results of the experiment, we believe that the application of fertilizers will be appropriate with biohumus.

Using this technology in a wildlife/field can solve several problems. First, it is greening the drylands. Secondly, when used in agriculture, it will reduce the need for irrigation. This technology can be of great marketing value due to its low cost. This technology meets environmental standards. Physiological and biochemical activation of seeds and seedlings of beans by treating them with nanoconcentration of new active 
biohumus increases their salt resistance and increases their competitiveness in terms of available oxygen and photosynthetic properties. It has also been experimentally established that when sowing beans from seeds treated with biohumus, due to the high synthetic ability of biomass above and below ground, much more root mass and plant residues are left behind than when sowing from conventional seeds. At the same time, the bean sprouts themselves act as a phytomeliorant, helping to enrich the soil with organic matter and thus improving its biological activity, chemical, physical and water-physical properties. In other words, this method is a new approach to old problems of land reclamation and is proposed to be introduced into production.

\section{Conclusion}

According to this study, a group of legume seedlings grown using biohumus during a month showed the highest rates of sprout length and root system length compared to groups grown on other soil types. In particular, they are approximately one and a half times higher than seedlings grown without using biohumus but with abundant moisture, which required three times more frequent watering. Without active moistening, plants in desert soil groups begin to dry up from the first week of seedling growth. Biochemical analysis of potassium, phosphorus and protein content in the seedlings of the group of beans grown with the use of biohumus is not significantly different from the control and black soil.

Thus, our experiments have shown that the new bihumus, containing sheep's wool, has a great influence on the growth of seedlings of beans with a decrease in chafing in irrigation. New fertilizers are important for irrigation and landscaping of agrocenoses and are an effective way of cultivating such soils. It should be noted that studies on the application of a mixture of fertilizers and biohumus on different soils will continue in the field.

\section{References}

1. A. Akhmetova, N. Mukhitdinov, A. Ydyrys, Pakistan J. Of Botany. 47(2), $511-515$ (2015).

2. A.B. Akhmetova, N.M. Mukhitdinov, A. Ydyrys, A.A. Ametov, Z.A. Inelova, M. Öztürk, J. of Animal and Plant Sc. 28(5), 1400-1404 (2018).

3. E.A. Bukenova, Z.M. Bassygarayev, A.B. Akhmetova, Z.K. Zhunusbayeva, A. Ydyrys, Research on Crops, 20(1), 210-214 (2019).

4. Yu chunWang, JunZhao, JiewenFu, WeiWei, Ecol. Indicators, 104, 659-668 (2019).

5. M. Kiley-Worthington, Agriculture and Environment, 6(4), 349-381 (1981).

6. M. Myrzabaeva, Z. Insepov, K.K. Boguspaev, D.G. Faleev, M. Nazhipkyzy, B.T. Lesbayev, Z.A. Mansurov, Eurasian Chemico-Technol. J. 19, 91-98. (2017). 